\title{
ACCESS TO SATISFACTORY WORK FOR FEMALE WORKERS IN THE NON-FORMAL SECTOR - CONTEXT AND POLICY GAPS IN VIET NAM
}

\author{
Nguyen Duc Huu \\ University of Trade Union \\ DOI: 10.46609/IJSSER.2021.v06i02.009 URL: https://doi.org/10.46609/IJSSER.2021.v06i02.009
}

\begin{abstract}
In Viet Nam, as in developing countries, women continue to be the main constituent of poorer, lower-income workers who are vulnerable to underemployment and unemployment. There are more precarious employment conditions than men. Vietnamese women are mainly employed in low-income occupations or vulnerable jobs. Women also make up the bulk of the unpaid family work, and in the "invisible" area of the informal economy. According to the ILO, About 7.8 million female workers are working in the informal sector. The share of women workers in the informal sector has risen to 59.6 per cent, much higher than the 31.8 per cent of male workers in the informal sector. The National Labor Code and the Law on Gender Equality provide that men and women are treated equally in the workplace, in terms of employment, salaries, bonuses, social insurance, working conditions, training and promotion. In reality, however, informal female workers are unaware of their basic rights, are exploited and harmed. With the current economic development, access to work It is a matter of concern for women workers. There should be a legal basis for developing and implementing policies.
\end{abstract}

Keywords: Policy, Work, Female workers, Informal, Vietnam

\section{Problem}

Since "Doi Doi" was launched in 1986, Vietnam has transformed from one of the poorest countries in the world to a low-middle-income country. The foreign-invested economy is encouraged by the Government of Vietnam to develop in many forms, popular as tax incentives, exemption from responsibilities for compliance with regulations on environmental protection and workers' responsibility. However, after more than 30 years of opening up, both the State and the people realized that the expensive lesson to pay is that "we cannot trade the environment and society for economic development and sustainable economic development is leaving no one behind" In 30 years of renovation, Vietnam has three times amended and promulgated the 
International Journal of Social Science and Economic Research

ISSN: 2455-8834

Volume:06, Issue:02 "February 2021"

Constitution, amending and promulgating more than 150 laws and laws, over 70 ordinances. Most recently, the National Assembly has adopted the revised 2013 Constitution and a series of laws to institutionalize the 2013 Constitution, which basically creates a legal basis for the formation and promotion of principles to ensure the implementation of progress and social justice in step by step, each socio-economic development policy and environmental protection

Currently, there are a number of names in the world such as informal sector; shadow economy; Underground economy... Although the names used vary, the terms generally reflect the nature of the activities of an un formal economic sector(UNIACTIV ECONOMY), as opposed to the orthodox sector. In fact, this region has long existed and has become an important part of the economy of all countries in the world, especially for developing countries such as Vietnam. THE UN-OFFICIAL ECONOMY is everywhere in Vietnam and grows incredibly strongly, typically at all times we can easily buy goods on the street or eat bowls of pho on the sidewalk, ride a motorbike or sew clothes at a neighbor's house.

The term "Un formal sector" was first proposed by Hart (1973) to describe a traditional economic sector in developing economies. Originally, the distinction between the formal sector and PCT was based on the distinction between paid and self-made workers.

This category was gradually expanded to cover all work changes caused by globalization, thus moving from the concept of "UN-ECONOMIC SECTOR" to the concept of "Un formal economy". A concept that covers both the NON-FORMAL AND NON-OFFICIAL SECTORS appearing in both the UN AND FORMAL SECTOR (ILO, 2002)

According to the ILO 1993 and 2002, oecd 2002, SNA 1993 and 2008, the "uns supervised economy" consists of three elements:

- Non-formal economy: exit (partly or completely) the regulations of the State (but not intentionally) - especially in developing countries: self-employment; investigate directly.

- Underground economy: avoiding state regulations (deliberately lowering sales); indirect access: black market (avoid tax audit).

- Illegal economy: illegal products (products and services: drug trafficking...) Accordingly:

- The non-formal economy(NON-OFFICIAL ECONOMY)) is an area in which official employment exists, which is a collection of units producing physical products and services with the main objective of creating jobs and incomes for those involved, contributing to GDP that the 
International Journal of Social Science and Economic Research

ISSN: 2455-8834

Volume:06, Issue:02 "February 2021"

official economic sector cannot reach. The NON-FORMAL ECONOMY covers many regions, many types, forms and objects of activity.

- Production and business units (PRODUCTION ANDBUSINESS) in the non-official economic sector bearing the characteristics of production and business households, without legal status, the operation of production and business units in the non-official economic sector is not intended to evade tax obligations, social security, violation of labor law or violation of law or any other regulatory regulations (National Account System - SNA, 4th Edition) These units are usually organized simply, small scale, with no or very little division between labor and capital are the inputs of production. Employment relationships (if any) are primarily based on coincidence, related relationships, or personal relationships, rather than contractual agreements with official guarantees.

Thus, the concept of activities of the UNIMPI Sector differs from similar activities of the hidden economy or the underground economy.

In 2007, the Institute of Statistical Sciences and the Long-Term Research, Institutional and Analytical Unit (DIAL) designed a survey plan to gather information on the NON-OFFICIAL ECONOMIC SECTOR and un formal employment in Vietnam. This strategy was developed in consultation with the recommendations of international organizations, adjusted to suit the conditions of Vietnam:

- The NON-FORMAL ECONOMIC SECTOR is defined as "all enterprises that do not have legal legality, produce at least one or several products and services for sale or exchange, do not register for business (without a business license) and do not belong to agriculture, forestry and fisheries" (agro-economic). Such businesses are called 1"non-official PRODUCTION and BUSINESS households", in accordance with the official word for this type of PRODUCTION AND BUSINESS. The removal of PRODUCTION AND BUSINESS activities in the agricultural sector out of the definition is due to the characteristics of agricultural and nonagricultural activities that differ, such as the weather, labor organization, income level,... and different investigative tools in these two areas. The official PRODUCTION AND BUSINESS households (with business registration) belong to the official economic sector.

\footnotetext{
${ }^{1}$ The ILO's definition left two possibilities open for the determination of the MD Sector: non-business registration standards and maximum scale standards (threshold for the most people working in business households). In an effort to apply the ILO's recommendation, the Delhi Group recommended that business households with fewer than 5 wage workers be non-official business households, with the primary purpose of comparing between countries. Not the same as the group Delhi, Institute of Science and Technology do not take the size of business households as the standard for determining official or official business households. However, in Vietnam, Nam also only 3\% of nonofficial business households with the size of 5 or more employees.
} 
International Journal of Social Science and Economic Research

ISSN: 2455-8834

Volume:06, Issue:02 "February 2021"

In Vietnam, PRODUCTION AND BUSINESS all enterprises and business households with business registration, regardless of size, are required to register their regular labor (with an employment contract of at least 3 months or more) of their units with the Social Insurance Agency of Vietnam. All jobs in the NON-FORMAL SECTOR are considered non-official jobs.

The Government of Viet Nam has been strongly committed to ensuring equality of opportunity and treatment for both men and women, which is reflected in the ratification of the two ILO Basic Conventions on the Elimination of Labour and Employment Discrimination in 1997 and is reflected in the National Labour Law. Therefore, understanding the access to satisfactory employment of female workers in the non-formal sector aims to strengthen the application of the principles of equality set out in the law and encourage the policy-making of policy makers, labor and social insurance experts and activists for women's progress. The access to satisfactory work of female workers is based on an analysis of working conditions and employment issues in different parts of Viet Nam and identifying the employment and social assistance needs and priorities of female workers in the non-formal sector.

Ensuring satisfactory access to work for female workers through the expansion of labour support policies that are not only suitable for workers in the formal sector but also more suitable for workers in the non-formal economic sector and rural economic sector. In addition, female workers in these areas bear additional burdens. Despite being recognized as equal before the law, Vietnamese women in addition to generating income for their families still have to take on most other family responsibilities. Leaders in agencies and workplaces are still predominantly men, women do not have fair opportunities for social protection and treatment in the profession. Female workers make up the majority of female workers in economic and occupational sectors where there is in fact no social and labour protection.

The results of the study are still very different, but have shown that the application of labor law and social insurance is a big challenge for ensuring access to satisfactory work for female workers. The indicators also show that there needs to be a balance between protecting female workers and strengthening equality of opportunities, occupational treatment, insurance and social support.

\section{Status of non-formal regional female workers through research results}

According to the ILO, Viet Nam currently has an unstable employment rate and a large number of people working in the non-formal sector and $95.7 \%$ of people working without a LABOUR CONTRACT. More than ever, sustainable employment is a pressing and practical issue. Integration is and will create inter-national labour flows, creating more competitive pressures on labour, labour mobility and migration. This will have a major impact on sector economic 


\section{International Journal of Social Science and Economic Research}

ISSN: $2455-8834$

Volume:06, Issue:02 "February 2021"

restructuring and labour restructuring. Integration has been causing the advantage of cheap labor to decline, increasing the pressure of transnational labor competition. In particular, deep integration means that Vietnam will face more fluctuations from the world economy. These fluctuations will quickly impact workers' employment and income. In this context, high-income workers, low-income workers, female workers will be the subject of the harshest impacts from these fluctuations. Their ability to respond is also lower, due to weaker access to social safety nets. Therefore, in order to effectively help this group, the social policy system must be well organized, covering 50 institutions, including female workers in the non-formal sector.

For the first time in 2015 and then in 2017, in Viet Nam, the Labour and Employment survey allowed the collection of labour data to be classified by institutional sector and separated from the official sector. Two specialized surveys conducted in Hanoi and Ho Chi Minh City (HB\&IS survey 2015, 2017) to learn more about the characteristics of BUSINESS households in general and especially of the PCT area.

- Working conditions are not guaranteed. Social insurance benefits, profit distribution, paid leave are almost nonexistent for employment in this area, even the proportion of dependent workers is not guaranteed any form of contract (text or agreement) has increased.

- Low income and temporary working conditions. A singly section of THE BUSINESS households in both cities operate in conditions where there is no fixed business location (e.g. hawkers, motorists hugging, ...). While the proportion of non-official BUSINESS households without fixed business locations in Hanoi has decreased (from 40\% - 2015 to $36 \%$ - 2017 for the old Hanoi, 31\% - 2017 if including the new Hanoi area), this rate in Ho Chi Minh City increased again (from $37 \%$ to $41 \%$ ), which shows that the operation of production and business households in this area has become more precarious.

There is an income gap in the non-formal sector in both cities. In 2017, in Hanoi, the average monthly income of workers was 4.6 million while median income was 2.9 million; respectively in Ho Chi Minh City is 3.7 million and 3 million.

- Low rate of migrant workers. Migrant workers in the UN economic sector in Hanoi and Ho Chi Minh City are low, at $6 \%$ and $17 \%$ respectively. This result is contrary to Harris- Todaro's OFFICIALECONOMY is model when it considers the UN sector as the backyard of migrant workers, when they can't find a job where they will penetrate the area. Although this model is accepted by many economists and migration researchers, this is not the case in Vietnam (at least in Hanoi and Ho Chi Minh City), which strictly controls immigration (through household management). 
International Journal of Social Science and Economic Research

ISSN: 2455-8834

Volume:06, Issue:02 "February 2021"

- The NON-OFFICIAL ECONOMIC SECTOR operates separately, with very few direct links to the official economy. This is because the main customer parts of these non-formal BUSINESS households are still households (consuming $90 \%$ of the supply volume).

- High stop-out rate: $15 \%$ in Hanoi and $21 \%$ in Ho Chi Minh City, these are only cautious estimates due to a significant number of BUSINESS households surveyed in 2015 but could not be found in 2017, and part of them may have been discharged.

Table 1: Sample rate and stop-work rate, 2015-2017(\%)

\begin{tabular}{|c|c|c|c|c|c|c|c|c|c|c|}
\hline \multirow[b]{2}{*}{ Industry group } & \multicolumn{5}{|l|}{ Hanoi } & \multicolumn{5}{|c|}{ Ho Chi Minh City } \\
\hline & $\begin{array}{l}\text { Still } \\
\text { active } \\
\text { (inves } \\
\text { tigate } \\
\text { d) }\end{array}$ & $\begin{array}{l}\text { Decom } \\
\text { missio } \\
\text { ning }\end{array}$ & $\begin{array}{c}\text { Exis } \\
\text { ts } \\
\text { (not } \\
\text { inve } \\
\text { stiga } \\
\text { ted) }\end{array}$ & $\begin{array}{l}\text { No } \\
\text { infor } \\
\text { matio } \\
n\end{array}$ & $\begin{array}{c}\text { Tot } \\
\text { al }\end{array}$ & $\begin{array}{l}\text { Still } \\
\text { active } \\
\text { (inves } \\
\text { tigate } \\
\text { d) }\end{array}$ & $\begin{array}{c}\text { Deco } \\
\text { mmis } \\
\text { sioni } \\
\text { ng }\end{array}$ & $\begin{array}{l}\text { Exists } \\
\text { (not } \\
\text { investi } \\
\text { gated) }\end{array}$ & $\begin{array}{l}\text { No } \\
\text { infor } \\
\text { mati } \\
\text { on }\end{array}$ & $\begin{array}{c}\text { Tot } \\
\text { al }\end{array}$ \\
\hline $\begin{array}{l}\text { Industryand } \\
\text { construction }\end{array}$ & 78.4 & 13.1 & 2.8 & 5.7 & 100 & 59.9 & 26.1 & 1.4 & 12.6 & 100 \\
\hline $\begin{array}{l}\text { Trade } \\
\text { Service }\end{array}$ & $\begin{array}{l}80.6 \\
71.9\end{array}$ & & $\begin{array}{l}2.5 \\
1.8\end{array}$ & $\begin{array}{l}4.4 \\
9.2\end{array}$ & $\begin{array}{l}100 \\
100\end{array}$ & & $\begin{array}{l}18.8 \\
20.0\end{array}$ & $\begin{array}{l}1.3 \\
0.3\end{array}$ & $\begin{array}{c}9.8 \\
11.5\end{array}$ & $\begin{array}{l}100 \\
100\end{array}$ \\
\hline $\begin{array}{l}\text { PCT Production } \\
\text { and Business } \\
\text { Households }\end{array}$ & 76.2 & 14.7 & 2.3 & 6.8 & 100 & 66.9 & 21.0 & 0.9 & 11.2 & 100 \\
\hline $\begin{array}{l}\text { Official } \\
\text { production and } \\
\text { business } \\
\text { households }\end{array}$ & 73.3 & 12.4 & 5.9 & 8.4 & 100 & 73.7 & 13.9 & 2.9 & 9.5 & 100 \\
\hline total & 75.7 & 14.2 & 3.0 & 7.1 & 100 & 68.7 & 19.2 & 1.4 & 10.7 & 100 \\
\hline
\end{tabular}

Source: HB\&IS Survey, Hanoi and Ho Chi Minh City, 2015 \&2017,GSO/ILO..

- High level of transition from formal to non-formal area. Although the proportion of SẢN XUÂT KINH DOANH PCT and official business households has not changed much between 2 years (2015 \& 2017), the dynamic analysis shows that there has been a marked shift between these two areas. Up to $15 \%$ of manufacturing and business households in Ho Chi Minh City and $31 \%$ of such households in Hanoi have joined the PCT area. 
International Journal of Social Science and Economic Research

ISSN: 2455-8834

Volume:06, Issue:02 "February 2021"

Table 2:Official/official conversion, 2015-2017

\begin{tabular}{lccccccc}
\hline & \multicolumn{3}{c}{ Hanoi (2017) } & & \multicolumn{2}{c}{ Ho Chi Minh City (2017) } \\
\hline $\mathbf{2 0 1 5}$ & Official & Official & Chung & $\mathbf{2 0 1 7}$ & Official & Official & Chung \\
\hline $\begin{array}{l}\text { Official } \\
(\%)\end{array}$ & 68,9 & 31,1 & $\begin{array}{c}100 \\
(18,8)\end{array}$ & $\begin{array}{l}\text { Official } \\
(\boldsymbol{\%})\end{array}$ & 84,7 & 15,3 & 100 \\
\hline $\begin{array}{l}\text { Non- } \\
\text { official } \\
(\%)\end{array}$ & 8,3 & 91,7 & $\begin{array}{c}100 \\
(81,2)\end{array}$ & $\begin{array}{l}\text { Non- } \\
\text { official } \\
(\boldsymbol{\%})\end{array}$ & 10,2 & 89,8 & 100 \\
\hline total (\%) & 19,7 & 80,3 & 100 & total (\%) & 29,8 & 70,2 & 100 \\
\hline
\end{tabular}

Source: HB\&IS Survey, Hanoi and Ho Chi Minh City, 2015 \&2017,GSO/ILO..

- The impact of the crisis is a sign of the weak nature of production and business households in the non-formal sector. The most pronounced effect is the decline in funds to spend and cuts in spending on food. In Ho Chi Minh City, which was more severely affected by the crisis, $37 \%$ of households operating in the PCT sector had to cut spending on food; the proportion of households having to cut health spending is quite high (17\%). These are clear signs that the weaker nature of the PCT sector is almost twice as high as that of households with formal sector business.

Table 3: Cuts to household spending in 2017

\begin{tabular}{|c|c|c|c|c|c|c|c|c|}
\hline \multirow{2}{*}{ Industry group } & \multicolumn{2}{|c|}{ Food and food } & \multicolumn{2}{|c|}{ Health } & \multicolumn{2}{|c|}{ Education } & \multicolumn{2}{|l|}{ Other } \\
\hline & Hanoi & $\begin{array}{l}\text { TP. } \\
\text { HCM }\end{array}$ & Hanoi & $\begin{array}{l}\text { TP. } \\
\text { HCM }\end{array}$ & Hanoi & $\begin{array}{l}\text { TP. } \\
\text { HCM }\end{array}$ & Hanoi & $\begin{array}{l}\text { TP. } \\
\text { HCM }\end{array}$ \\
\hline $\begin{array}{l}\text { Industry and } \\
\text { construction }\end{array}$ & 7,6 & 29,6 & 7,4 & 13,0 & 5,5 & 5,1 & 15,3 & 28,1 \\
\hline Trade & 7,6 & 38,3 & 8,5 & 15,6 & 7,0 & 7,9 & 13,4 & 19,9 \\
\hline Service & 12,9 & 38,5 & 6,3 & 18,6 & 4,7 & 6,6 & 16,0 & 26,0 \\
\hline $\begin{array}{lr}\text { PCT } & \text { Production } \\
\text { and } & \text { Business } \\
\text { Households }\end{array}$ & 9,5 & 36,8 & 7,5 & 16,7 & 5,8 & 6,7 & 14,8 & 24,8 \\
\hline $\begin{array}{l}\text { Official production } \\
\text { and business } \\
\text { households }\end{array}$ & 5,9 & 18,4 & 5,8 & 8,2 & 4,9 & 4,3 & 5,9 & 18,7 \\
\hline total & 8,9 & 33,6 & 7,2 & 15,2 & 5,7 & 6,3 & 13,4 & 23,7 \\
\hline
\end{tabular}

Source: HB\&IS Survey, Hanoi and Ho Chi Minh City, 2015 \&2017,GSO/ILO.. 


\section{International Journal of Social Science and Economic Research}

ISSN: $2455-8834$

Volume:06, Issue:02 "February 2021"

Non-formal workers in Viet Nam are often low-income and in-er00s, long working hours and little access to skills development opportunities. Because they are not recognized, registered or managed so they are not protected by labour market institutions, workers in the non-political sector face the risk of becoming "working class poor".

Experience has shown that female workers in the non-government sector and their families are often disadvantaged because they are not governed by labor laws. For example, for health and safety requirements related to working conditions, they do not receive support from social assistance programs. In addition, the voices of female workers in the non-formal sector are rarely mentioned in the policy decision-making process. Businesses in the formal economy face unfair competition from the non-government sector due to prices of goods and services being cut because they do not contribute to social insurance nor taxes. Like in many emerging economies around the world, the non-formal sector in Viet Nam - which accounts for a large part of the national workforce - plays an important role in the daily lives of Vietnamese people.

While an important source of job creation and income opportunities for many Vietnamese, the lives of female workers in the non-formal sector in Viet Nam are characterized primarily by low incomes and unsi guarantees of working conditions, making them more vulnerable to external impacts. The government is currently working to extend protections to this working group through improving the national legal framework and policy development to address the challenges of the un formal economy.

\section{Policy gaps for women in the non-formal sector}

Recognizing the important role of the non-formal sector in job creation, income and poverty reduction, Viet Nam has been constantly adding and improving its legal system and policies to support the non-formal sector as well as protect the rights of the female workforce working in this region.

Article 35 of the 2013 Constitution stipulates: "Citizens have the right to work, choose careers, jobs and workplaces." Article 5 of the Labor Code 2012 also stipulates that workers have the right to "work, freely choose jobs, occupations, apprenticeships, improve professional qualifications and not be discriminated against". Thus, workers in particular and workers in general, have the right to choose jobs suitable to their health, circumstances and professional qualifications. They also have the right to choose the workplace suitable for each person's living conditions, health and preferences, can choose directly or through job referral organizations to find work ... (Article 10 blld 2012). The Constitution guarantees the freedom to work for all citizens, as provided in Article 33 of the 2013 Constitution: "Everyone has the right to freedom of business in accordance with industries that are not prohibited by law." It can be seen that 


\section{International Journal of Social Science and Economic Research}

ISSN: $2455-8834$

Volume:06, Issue:02 "February 2021"

women or men have the right to freely do business in sectors and professions that are not prohibited by law. The 2013 Constitution protects the rights of people as well as equal rights in career, employment and workplace choices. Clause 2, Article 153 of the 2012 BLLD also states: "Encouraging employers to create conditions for female employees to have regular jobs, apply widely the working regime according to flexible schedules, work incompletely, assign jobs at home." Thus, the labor law of our country also has its own incentives for workers to get regular jobs with flexible time to carry out their own responsibilities.

In the field of recruitment, employers, employment equality as well as creating employment sustainability for men and women is considered as the development goal of the whole world as well as in each country. The laws of our country have made provisions on anti-discrimination against male and labor workers in the field of employment, especially in labor recruitment. Clause 1, Article 154 of the Civil Code 2012stipulates that employers must "Ensure the implementation of gender equality and measures to promote gender equality in recruitment, use, training, working time, rest time, wages and other regimes." In addition, Article 13 of the Law on Gender Equality 2006provides for gender equality in the field of labor including: (i) Men and women are equal in standards and age when recruiting, treated equally in the workplace in terms of employment, wages, bonuses, social insurance, working conditions and other working conditions. (ii) Men and women are equal in standards and age when they are promoted and appointed to hold titles in standard professions and occupations. cdanh Thus, Viet Nam's labour law has focused on the equal rights of labour in many respects, these provisions help protect labour, avoid discrimination, in accordance with the standards set by the CEDAW Convention. With the competitive situation between enterprises today, profit criteria are the top concern for businesses.

Clause 1, Article 152 of the Civil Code 2012 stipulates: "Employers must base their work standards on each type of job to recruit and arrange labor." Labour is more susceptible to disease than men, and they are just as incapable of carrying heavy goods as men, and with their health diminished when they become pregnant and give birth. Therefore, labor law also provides for employers to rely on the ability and health of workers to recruit them to suitable positions as well as arrange jobs to meet the needs of both parties.

In accordance with the labor law on working hours and rest, there are incentives for laborers, helping them to perform well the functions of wife, motherhood as well as fertility care to ensure the best conditions for laborers to develop comprehensively physically, serving labor reproducience. Clause 1.2 Article 155 of the Labor Code 2012 stipulates: "Employers are not allowed to use female employees to work at night, work overtime and travel long distances in the following cases: a) Pregnancy from the 7th month or from the 6th month if working in upland, 


\section{International Journal of Social Science and Economic Research}

ISSN: $2455-8834$

Volume:06, Issue:02 "February 2021"

remote, remote areas, borders, islands; b) Raising children under 12 months of age. 2. Female employees who work hard during pregnancy from the 7th month, are transferred to lighter jobs or are reduced by 01 hour of daily work while still enjoying full pay" This regulation on the oneside protects labor force during maternity and child support, as well as incentives to help workers stabilize their incomes. The State also encourages employers to create conditions for workers to have regular jobs, widely apply the working regime according to flexible schedules, work incompletely, assign jobs at home. Clause 5, Article 155 of the Labor Code 2012 and Decree $85 / 2015 / \mathrm{ND}-\mathrm{CP}$, in order to protect the animal health of labor, the labor law stipulates: "Female employees during menstruation are allowed to take 30 minutes of leave per day; during the child support period under 12 months of age, 60 minutes of leave per day during the working period. The time off is still entitled to full salary under the LABORCONTRACT". HỢP ĐỒNG LAO ĐỘNG

Although Viet Nam's laws have made great achievements in accessing and ensuring the rights and interests of female workers, there are still many shortcomings. This is a policy gap that needs to be added and perfected in the future. Namely:

Firstly, to issue guiding documents leading to policies and regulations that do not come to life, for example: (i) Decree No. 39/2015/ND-CP stipulating policies to support poor women who are ethnic minorities in childbirth in accordance with population policies (after 9 years since the Law on Gender Equality was promulgated, this policy has not yet been implemented; The Decree is issued but must wait for the Circular to be guided); (ii) in the field of education and training, Clause 4, Article 14 of the Law on Gender Equality stipulates that "female cadres, civil servants and public employees when participating in training and retraining carrying children under thirty-six months are supported in accordance with the Government's regulations" or in the political institutions, in point a clause 5 Article 11 of the Law on Gender Equality stipulating "ensuring the appropriate proportion of women in the appointment of titles in state agencies in accordance with the national objectives of gender equality"; however, after more than 10 years of effective law, the above provisions are difficult to enforce because there are no guiding documents; (iii) the development of specific policies to support gender equality activities in remote and ethnic minority areas and areas with particularly difficult socio-economic conditions has not been implemented even though Decree No. 48/2009/ND-CP has been issued for nearly 7 years (Clause 2, Article 19).

Secondly, a number of policies and measures to promote gender equality have been enacted but in practice have not been effective, such as: The Law on Equality provides "priority" in some areas of family and social life, but in practice is creating barriers to women's equal participation in social activities. For example, the regulation "Enterprises that use many female employees are 


\section{International Journal of Social Science and Economic Research}

ISSN: $2455-8834$

Volume:06, Issue:02 "February 2021"

entitled to tax and financial incentives in accordance with the law" (point a clause 2 Article 12) is a measure to promote gender equality in the economic sector but in practice most businesses that use more female workers do not benefit. This is because the processes and procedures for enjoying tax incentives for businesses are quite complicated, the amount of tax reduction has not offset the costs when applying incentives for female employees, so businesses often hesitate or do not want to access this preferential policy. While the policy of supporting and protecting female employers is lacking and not specific, the current policies to protect female employees are relatively adequate, thus not encouraging female employers.

Thirdly, some regulations ensure gender equality from the perspective of the law but have not ensured real gender equality due to lack of guaranteed conditions. Specifically: (i) stipulating that "Men and women are equal in professional standards and age when promoted and appointed to the same management and leadership positions of agencies and organizations" (Clause 4, Article 11 of the Law on Gender Equality), although there are provisions, in practice, the law is still difficult. It is worth noting that, the issue of regulating the retirement age of women and men is different 5 years while the regulation of "equality" in the calculation of management term (5 years) is not reasonable; (ii) or equal treatment regulations to ensure equality - that is, the same regulation between women and men. For example, Article 20 of Decree No. 18/2010/ND-CP of the Government stipulates 05 conditions for civil servants to be sent to train masters and doctor degrees including: (i) having worked for full 5 years or more; (ii) specialized training suitable for employment positions; (iii) not more than 40 years of age from the time they are sent for training; (iv) committing to continue performing tasks and public duties after completing the training program for at least 03 times the training period; (v) have at least 03 consecutive years of successfully completing the task". This regulation is equal between men and women, however, when analyzing these conditions in the correlation between male and female civil servants there will appear a disparity in the number of years of opportunities to implement each person's rights in the direction of disadvantage in favor of women (4-5 years lower than men). This disparity stems from the gap that interrupts pregnancy, childbirth and child support, the difference of 5 years of retirement while the age of being sent to school is the same.

Fourthly, many regulations are also meathy, difficult to quanding (appropriate proportion of female national assembly deputies; appropriate proportion of women in the appointment of titles in state agencies); regulation of financial resources for gender equality activities ...

\section{Conclusion}

Un formal and un formal employment is abundant and varied, with no exclusion of one or anyone else able to participate in non-formal work. Even in the public sector or foreign-invested 


\section{International Journal of Social Science and Economic Research}

ISSN: $2455-8834$

Volume:06, Issue:02 "February 2021"

sector, un formal employment still attracts workers of different levels, especially female workers. Part-time workers are more focused on those working in the formal sector than those in the nonformal sector. That makes the non-formal workforce growing. Individual characteristics also influence the decision to register or not to register for business in the non-agricultural sector and influence the decision to work in the non-formal sector.

Labour market policies and governance should be designed to ensure balance, on the one behalf of ensuring labour market development under a long-term strategy but not making it more difficult for the region and un formal employment; on the other behalf, reforming and expanding the formal regional legal framework to improve the quality and employment of this region, facilitate access to the formal sector. The strategy framework for improving labour market governance capacity and supporting the non-formal employment sector encouraged by the ILO includes: (1) Government policies and legislation to consider removing barriers that encourage micro and small businesses. Creating conditions and improving the environment for small business development is a matter of survival to reduce poverty. (2) Labour market partners such as workers' representatives and employers should be encouraged to enhance regional representation and un formal employment. (3) Micro and small businesses need credit access advice and support to improve productivity and improve working conditions. The social security system to support and prevent households from falling into poverty due to risks is of particular importance. (4) The Labor Inspectorate should insist on technical assistance to improve working conditions and prevent accidents as well as labor abuses and violations of employers' labor laws. (5) The process of urbanization should take into account the needs of small enterprises and workers for factories, houses, public transport, supply of electricity and water safely at cheap prices.

Labor market policies, social insurance policies, health insurance, unemployment insurance should expand the coverage of programs and ensure the safety of funds to minimize the level of risk when participants and their families are reduced or lost sources of income. Social assistance policies should aim to expand scope and reach, improve the effectiveness of assistance to respond promptly to variables and risks, contribute to sustainable poverty reduction and protect vulnerable groups. Recognizing and protecting the legitimate rights of employees and employers, especially on business rights, the right to implement regulations on minimum wages, the right to implement regulations on minimum wages, working conditions and gender equality. At the same time promoting the active role of partners in the labor market, enhancing the role of dialogue, institutions and promoting the establishment of representative organizations protecting the interests of vulnerable groups 


\section{REFERENCES}

1. General Statistics Office - Institute of Labour Science - Society :Labour - Employment Survey Report(HB\&IS Survey 2015, 2017)

2. National Strategy on Gender Equality 2011-2020: (Regulation 2351/QD-TTg)

3. ILO (2002) Decent jobs and the non-formal sector, Report VI, Session 90 of the International Labour Conference in Geneva.

4. ILO (2013): Equality in labour and social protection for female workers in the formal and non-formal sector: Findings for policy-making

5. ActionAidVietnam (2015)SAN SHARING IS LOVING: Summary of wageless care policy recommendations

6. Hart, K. (1973). Informal Income Opportunities and Urban Employment in Ghana, The Journal of Modern African Studies, 11 (1), 61-89. 